\title{
Proposal of nursing care plan in people hospitalized with AIDS*
}

\author{
Proposta de plano de cuidados de enfermagem para pessoas internadas com Aids \\ Propuesta de plan de cuidados de enfermería para personas internadas con SIDA
}

Vinicius Lino de Souza Neto ${ }^{1}$, Richardson Augusto Rosendo da Silva ${ }^{1}$, Cristiane da Costa Silva ${ }^{1}$, Rosangela Vidal de Negreiros $^{2}$, Cintia Capistrano Teixeira Rocha ${ }^{1}$, Maria Miriam Lima da Nóbrega ${ }^{3}$

How to cite this article:

Souza Neto VL, Silva RAR, Silva CC, Negreiros RV, Rocha CCT, Nóbrega MML. Proposal of nursing care plan in people hospitalized with AIDS. Rev EsC Enferm USP. 2017;51:e03204. DOI: http://dx.doi.org/10.1590/S1980-220X2016027203204

* Extracted from the masters' dissertation "Diagnósticos, resultados e intervenções de enfermagem da CIPE para pessoas vivendo com Aids", Universidade Federal do Rio Grande do Norte, 2016.

${ }^{1}$ Universidade Federal do Rio Grande do Norte, Departamento de Enfermagem, Natal, RN, Brazil.

${ }^{2}$ Universidade Federal de Campina Grande, Campina Grande, PB, Brazil.

${ }^{3}$ Universidade Federal da Paraíba, Centro de Ciências da Saúde, João Pessoa, PB, Brazil.

\begin{abstract}
Objective: To elaborate and validate a proposal for a nursing care plan in people hospitalized with AIDS, in an infectious disease unit, using ICNP ${ }^{\circledR}$ version 2015. Methods: A cross-sectional study, followed by validation of content, performed with 20 nurses and 120 people, living with AIDS in an infectious disease unit of a hospital of infectious diseases in Northeast Brazil. The methodological trajectory was carried out in the following stages: elaboration of the diagnosis, nursing outcomes; Initial proposal of nursing interventions; Preparation of a care plan; And validation of the plan by field experts. Results: 42 diagnoses were elaborated and validated, 33 presented CVI $\geq 0.80$ $(55.42 \%)$ among field experts. From this quantitative, 228 interventions were elaborated and 41 obtained a CVI $\geq 0.80(44.78 \%)$, considered validated. Conclusion: The study allowed us to identify and validate nursing diagnoses, outcomes and interventions for the use in clinical practice, aiming to subsidize the process of care for people with AIDS.
\end{abstract}

DESCRIPTORS

Acquired Immunodeficiency Syndrome; Nursing Process; Nursing Diagnosis; Classification. 


\section{INTRODUCTION}

The Acquired Immunodeficiency Syndrome (AIDS) is still considered one of the most serious public health problems, representing a dynamic and unstable global phenomenon. In addition, the condition prompts concern that affects the whole world, facing the large responsibilities of attention and specific care, which require those involved with care to reinforce actions that positively influence the lives of people infected by the aforementioned virus ${ }^{(1-2)}$.

Thus, it is up to the nurse, as a member of the health team, to improve the care, through the restructuring of their practices, in order to use specific Nursing instruments that will increase the care in people with AIDS, increasing their visibility and their professional recognition. In this sense, the Systematization of Nursing Care (SNC) emerges as an instrument that assists in the provision of nursing care, reducing complications during treatment and/or facilitating client adaptation and recovery, as well as identifying priority needs and the elaboration of an individualized, humanized and integrality of care $^{(3)}$.

To this end, the International Classification for Nursing Practice $\left(\mathrm{ICNP}^{\circledR}\right)$ emerges as a unifying framework for the different classification systems of the professional practice elements - nursing diagnoses, outcomes and interventions -, collaborating for critical thinking, scientific and resoluteness of the nurse ${ }^{(4)}$. Such a classification system has its structure developed based on the Seven Axes Model, being these: Focus, Judgment, Means, Action, Time, Location and Client ${ }^{(4-5)}$.

In addition, the $\mathrm{ICNP}^{\circledR}$ complements any systematic activity that may be developed by the nurse, among them the care plan, which is characterized as a tool of the professional's daily practice and that allows care in the organization of the work of the nursing team. In addition to optimizing the practice, the care plan must work towards the basic human needs, characterized by the aspects related to food, water, safety, love, necessary for survival and health. Thus, the implementation of the care plan, based on a theoretical framework, guides and enhances the practice, directing the observation of the phenomena, the nursing intervention and the outcomes to be expected ${ }^{(5)}$.

Therefore, the rationale for the development of the study is based primarily on the search for scientific productions published during the last 5 years on the subject, in the following databases: Latin American and Caribbean Literature (Lilacs), PUBMED, SCOPUS, Web of Science and CINAHL, through the descriptors: Nursing Processes; Nursing; Nursing Diagnosis and Acquired Immunodeficiency Syndrome. There was scarcity of scientific productions that addressed the applicability of SNC to people living with AIDS, especially regarding the use of $\mathrm{ICNP}^{\circledR}$ for these clients ${ }^{(6-7)}$.

In addition to this scientific production problem, the study provides a greater dimension and broadening of knowledge about care for people living with AIDS, as well as emphasizes the importance of systematic practices in the field of infectology and the implementation of new nursing technologies, the ICNP ${ }^{\circledR}$ is an example. The study also intends to carry out these practices with the clients cited in these databases in the future. In view of this, the question is: What are the care needs identified in people living with AIDS? Consistent with this research-question, the study aims to elaborate and validate a proposal for a care plan for people living with AIDS, using the ICNP ${ }^{\circledR}$ version 2015.

\section{METHOD}

Cross-sectional, quantitative approach study, followed by content validation conducted by field experts, carried out with people living with AIDS and nurses from a hospital of infectious diseases in Northeast Brazil. The methodological trajectory was carried out in four stages: a) elaboration of the diagnoses; b) nursing outcomes; c) initial proposal of nursing interventions; d) elaboration of a care plan and content validation of the care plan by nurses who provide care to people with AIDS.

In the first step, the sample was calculated from the arithmetic mean of the number of people living with AIDS who were cared for between 2010 and 2014, reaching 300.2 patients per year. Thus, the formula for finite populations was adopted, which takes into account the $95 \%$ confidence level, the $5 \%$ sampling error and the population size ${ }^{(8)}$.

After applying the formula, we found the study sample: 120 people living with AIDS. The selection was for convenience, consecutively, adopting the following inclusion criteria: having been clinically diagnosed with AIDS, being over 18 years old and hospitalized at the time of data collection. As exclusion criteria: those people who were unaware of their diagnosis and who did not have preserved cognitive functions, evaluated through the Mini Mental State Examination ${ }^{(9)}$.

The data collection was performed through an interview script and physical examination for people living with AIDS, based on Wanda de Aguiar Horta's basic human needs theory. This instrument included: sociodemographic aspects, clinical data (transmission form, time of diagnosis, presence of infections, adherence to antiretrovirals, drugs and laboratory tests) and empirical indicators of basic psychobiological, social and spiritual human needs.

To validate content, appearance, clarity and applicability of the instrument, expert nurses were searched in the Lattes platform (a national curriculum database created, above all, to follow up researchers' work in Brazil) of the National Council of Scientific and Technological Development (Conselho Nacional de Desenvolvimento Científico e Tecnológico - CNPq). These are research experts in the following fields: Nursing; Subareas: Nursing of contagious diseases; Systematization of nursing care; International Classification for Nursing Practice (ICNP $\left.{ }^{\circledR}\right)$. The sample adopted by the research was based on Fehring's framework, which deduces that the minimum number of experts should be 25 and the ideal number, 50 participants ${ }^{(10)}$. Thus, the experts were intentionally selected and the author's eligibility criteria were adopted, as shown in Chart 1. In this sense, 45 experts were selected, who scored above five points, but only 27 responded the script.

For the analysis of the expert nurses, we sent them the script in Microsoft Word version 2010, which contained, 
for each variable, an agreement column and a disagreement column. If they did not agree with the variable, we suggested they should suggest improvements in the suggestion column, which would later be analyzed by the researchers and returned to the experts, aiming at a new appreciation.

The suggestions pointed out by the experts are directed to each variable, such as laboratory tests, viral load, infection time and aspects of morbidities, since they refer to the object of the study. Thus, the modifications were contemplated in the study and adapted according to reality. The instrument was then returned for evaluation of this group with no further suggestion pointed out. For greater reliability, a pre-test was also performed with $10 \%$ of the sample of people living with AIDS, so that possible gaps were identified, and there was no need for modifications.

Chart 1 - Criteria for selection of experts proposed by Fehring Natal, RN, Brazil, 2016.

\begin{tabular}{|l|c|}
\hline CRITERIA & SCORE \\
\hline Master's Degree in Nursing & 4 \\
\hline $\begin{array}{l}\text { Master's Degree in Nursing with dissertation related to the } \\
\text { Content relevant to the diagnosis under study }\end{array}$ & 2 \\
\hline $\begin{array}{l}\text { Publication of studies on nursing diagnosis in relevant } \\
\text { journals }\end{array}$ & 2 \\
\hline $\begin{array}{l}\text { Study published on nursing diagnosis and content relevant } \\
\text { to this specific area }\end{array}$ & 2 \\
\hline \begin{tabular}{l} 
PhD on nursing diagnosis \\
\hline $\begin{array}{l}\text { Clinical experience of at least 1 year in the area of the } \\
\text { study diagnosis }\end{array}$
\end{tabular} & 2 \\
\hline $\begin{array}{l}\text { Certificate of clinical practice relevant to the area of the } \\
\text { study diagnosis }\end{array}$ & 1 \\
\hline
\end{tabular}

Once the script was elaborated, the data collection took place from August to September 2015. The elaboration of the diagnoses was procedural, that is, after the data collection performed through the validated instrument, two of the researchers of the present study, one with a master's degree and one with a $\mathrm{PhD}$, identified the priority nursing centers, so that the diagnoses and nursing results using $\mathrm{ICNP}^{\circledR}$ version 2015 could be elaborated.

In this process of elaboration of nursing diagnosis statements, Gordon's diagnostic reasoning was adopted, which uses the hypothetical-deductive model, considering the predictive testing of the hypothesis as the key of the diagnostic process, defining that the diagnostic process involves four perceptual and cognitive activities ${ }^{(11)}$. For the structuring of the diagnoses, nursing results by ICNP ${ }^{\circledR}$, the statements should be composed of a term from the axis focus and judgment ${ }^{(12)}$.

A database was built, using Microsoft Excel 2009, with the respective diagnoses and nursing outcomes for people with AIDS. For each diagnosis, the two researchers prepared an initial proposal for the respective nursing interventions based on ICNP ${ }^{\circledR}$, which should contain a term of the axis action and client, in accordance with ISO resolution $18.104^{(12)}$.

Finally, a proposal of a care plan with the respective diagnoses, outcomes and nursing interventions was structured. For the clinical validation of the plan, there were 20 nurses from the practice of care, who met basic requirements, such as: having at least 5 years of experience in the practice of care for people living with AIDS; and being Graduate and/ or having residency in the area of infectology. The expert nurses were responsible for assessing whether the proposed statements were applicable to the clients. However, before sending the plan electronically, a course for nurses was held, in October 2015, with a 40-hour workload, in the auditorium of the hospital unit, given by the researchers of the present study.

The objective of the training was to qualify nurses on the clinical and epidemiological aspects of AIDS; nursing care to these clients, highlighting nursing technologies such as SAE, $\mathrm{PE}$, Nursing Diagnostics and $\mathrm{ICNP}^{\circledR}$, with emphasis on clinical reasoning and practice of nursing diagnosis. During the presentation of these topics, constant elements were discussed in the instrument of data collection. In addition, a practical activity was organized, proposed by the researchers, through fictitious clinical cases, with the objective of analyzing the diagnostic inferences of the expert nurses.

Finally, a spreadsheet was sent to the nurses, containing the respective diagnoses, outcomes and nursing interventions and, for each statement, a column of agreement, disagreement and suggestions was elaborated. The validation phase occurred between November and December 2015. In case of disagreement of the claims, it was requested that the suggestions should be presented for adequacy to the reality of the nursing practice.

In order to perform the analysis of the agreement of the experts, the method called Content Validity Index (CVI) was adopted, which measures the proportion of experts who agree on certain aspects of the instrument and its items, represented by the diagnostic/outcomes statements and nursing interventions, which were evaluated for their use in the practice of care for people with AIDS. The items that obtained an agreement of at least $\mathrm{CVI} \geq 0.80$, which is considered optimal, were considered validated.

The study also met the ethical precepts of research involving human subjects, with favorable evaluation by the Research Ethics Committee of the Universidade Federal do Rio Grande do Norte (UFRN), according to the protocol number 1.117.410 and Certificate of Presentation for Assessment Ethics n 47380915.2.0000.5537.

\section{RESULTS}

The study included 120 people living with AIDS, with a minimum age of 35 years and a maximum of 45 years $(67.75 \%)$, average of 40.27 years. The majority were female (57.78\%), married (63.85\%), self-employed (41.33\%), white (54.21\%) and Catholic (85.74\%). Regarding the characterization of the expert nurses, 18 (64.28\%) had more than 16 years of professional experience in the field of infectious diseases, they had either a Certificate of specialist (58.64\%) or a masters' degree $(41.36 \%)$. In the identification of the data, the focus of the nursing practice was obtained, which were the empirical indicators for diagnosis, nursing results. Chart 2 shows the focuses of nursing practice, grouped by their respective basic human needs. 
Chart 2 - Distribution of the elements of nursing practice on people living with AIDS - Natal, RN, Brazil, 2016.

\begin{tabular}{|c|c|}
\hline Elements of practice & Basic human needs \\
\hline $\begin{array}{l}\text { Noisy, rapid and abdominal breathing; use of accessory muscles; antero- } \\
\text { posterior diameter; peripheral and central cyanosis; filiform pulse; bleeding; } \\
\text { heart rate; secretion. }\end{array}$ & Oxygenation and vascular regulation \\
\hline $\begin{array}{l}\text { Hydration; peripheral and central edema; resected mucous membranes; } \\
\text { abdominal circumference; peritonitis; positive water balance. }\end{array}$ & Hydration and electrolytic regulation \\
\hline $\begin{array}{l}\text { Weight loss; malnourished; probe diet; lesions in the nasopharynx and } \\
\text { oropharynx; dysphagia; dyspepsia; nausea; vomiting; diarrhea; flat abdomen, } \\
\text { with hydro-air noises; delayed bladder catheter and dysuria; constipation. }\end{array}$ & Nutrition and excretion \\
\hline Use of medications for sleep; fatigue; adynamia; stress. & Sleep and rest \\
\hline $\begin{array}{l}\text { Average temperature of } 39.5^{\circ} \mathrm{C} \text {; oral cavity; dental flaws; dry skin; seborrhea; } \\
\text { pediculosis; ecchymosis and papule; hyperemia in the sacral region. }\end{array}$ & Thermal regulation, body care and cutaneomucous integrity \\
\hline $\begin{array}{l}\text { Use of alcohol, drugs and smokers; recurrent infections, leukocytosis; cessa- } \\
\text { tion of antiretroviral use. }\end{array}$ & $\begin{array}{l}\text { Physical security of the environment, immunological regulation, } \\
\text { therapeutics }\end{array}$ \\
\hline $\begin{array}{l}\text { Easy to cry; sadness; lack of self-confidence; fear of death; body changes; } \\
\text { fear of exposing their ideas, future perspectives. }\end{array}$ & Self-realization, Self-esteem and Self-image \\
\hline Anguish; Lack of spiritual belief. & Religious/Spirituality \\
\hline
\end{tabular}

From the elements of nursing practice, 42 diagnoses were produced, but 33 were validated, which presented a CVI $\geq 0.80(55.42 \%)$ among expert nurses, categorized according to basic human needs, as shown by the Table 1.
In this sense, from the diagnoses, 228 interventions were elaborated and evaluated by the experts, and only 41 interventions obtained a CVI $\geq 0.80$ (44.78\%), and were therefore validated. Chart 3 shows the diagnoses/outcomes and interventions, according to ICNP ${ }^{\circledR} 2015$.

Table 1 - Basic Human Needs changed in people living with AIDS from ICNP® 2015 - Natal, RN, Brazil, 2016.

\begin{tabular}{|c|c|c|c|}
\hline \multicolumn{4}{|c|}{ BASIC HUMAN NEEDS } \\
\hline \multicolumn{4}{|c|}{ Psychobiological needs } \\
\hline Nursing diagnosis statements & & $f(\%)$ & $\mathrm{CVI} \geq \mathbf{0 . 8 0}$ \\
\hline \multicolumn{4}{|l|}{ Oxygenation and vascular regulation } \\
\hline Dyspnea & & 94 & 1.0 \\
\hline Increased heart rate & & 90 & 1.0 \\
\hline Bleeding & & 79 & 0.70 \\
\hline Expectoration & & 70 & 0.50 \\
\hline \multicolumn{4}{|l|}{ Hydration and electrolytic regulation } \\
\hline Impaired swallowing & & 82 & 0.90 \\
\hline Dehydration & & 80 & 0.80 \\
\hline Hyperthermia & & 80 & 0.80 \\
\hline \multicolumn{4}{|l|}{ Nutrition and excretion } \\
\hline Cachexia & & 78 & 0.70 \\
\hline Impaired Defecation & & 74 & 0.62 \\
\hline Committed spontaneous bladder elimination & & 74 & 0.60 \\
\hline Excessive intestinal elimination & & 71 & 0.50 \\
\hline Vomit & & 70 & 0.50 \\
\hline \multicolumn{4}{|l|}{ Sleep and rest } \\
\hline Insomnia & & 68 & 0.42 \\
\hline \multicolumn{4}{|c|}{ Thermal regulation, body care and cutaneomucous integrity } \\
\hline Impaired skin integrity & & 68 & 0.40 \\
\hline Impaired oral cavity hygiene & & 65 & 0.40 \\
\hline Impaired scalp hygiene pattern & & 61 & 0.35 \\
\hline \multicolumn{4}{|c|}{ Physical security of the environment, immunological regulation, therapeutics } \\
\hline Exposure to contamination & & 60 & 0.35 \\
\hline
\end{tabular}


BASIC HUMAN NEEDS

Psychobiological needs

\begin{tabular}{|c|c|c|}
\hline Nursing diagnosis statements & $f(\%)$ & $\mathrm{CVI} \geq \mathbf{0 . 8 0}$ \\
\hline Tobacco abuse & 60 & 0.30 \\
\hline Drug abuse & 59 & 0.30 \\
\hline Alcohol and tobacco abuse & 55 & 0.30 \\
\hline \multicolumn{3}{|l|}{ Psychosocial needs } \\
\hline \multicolumn{3}{|c|}{ Communication / Learning (health education) / Sociability / Recreation and leisure } \\
\hline Acceptance of the impaired therapeutic regimen & 81 & 1.0 \\
\hline Loneliness & 80 & 1.0 \\
\hline Fear & 79 & 0.80 \\
\hline Communication impaired & 75 & 0.70 \\
\hline Altered state of consciousness & 70 & 0.70 \\
\hline Social isolation & 69 & 0.65 \\
\hline Low health knowledge & 65 & 0.60 \\
\hline \multicolumn{3}{|l|}{ Self-realization, Self-esteem and Self-image } \\
\hline Acceptance & 61 & 0.50 \\
\hline Body Modification & 60 & 0.50 \\
\hline Socialization & 50 & 0.40 \\
\hline Will to Live & 47 & 0.40 \\
\hline \multicolumn{3}{|l|}{ Spiritual needs } \\
\hline \multicolumn{3}{|l|}{ Religious / Spirituality } \\
\hline Spiritual Anguish & 47 & 0.40 \\
\hline
\end{tabular}

Chart 3 - Proposal of the care plan for people living with AIDS from the nursing diagnoses of CIPE ${ }^{\circledR}$ version 2015 - Natal, RN, Brazil, 2016.

\begin{tabular}{|c|c|}
\hline DIAGNOSTICS / NURSING OUTCOMES & $\begin{array}{l}\text { NURSING INTERVENTIONS } \\
\text { CVI } \geq \mathbf{0 . 8 0} \text { - Scores }\end{array}$ \\
\hline $\begin{array}{l}\text { Hyperthermia: state in which the individual presents a decrease of the } \\
\text { physical and chemical processes that promote the production or loss of } \\
\text { heat, maintaining the organism with more or less constant temperature, } \\
\text { independently of the variations of the external environment. }\end{array}$ & $\begin{array}{l}\text { Teach the patient the early warning signs of hyperthermia (cold skin, } \\
\text { pallor and redness); avoid drafts in the environment; avoid infusion of } \\
\text { ice liquids; keep the patient hydrated; monitor color and body tempera- } \\
\text { ture; monitor level of consciousness; monitor intake and elimination of } \\
\text { liquids; monitor the electrolyte imbalance. }\end{array}$ \\
\hline $\begin{array}{l}\text { Dehydration: state in which the individual has decreased balance of } \\
\text { intake and elimination of liquids and electrolytes of less than } 2,600 \mathrm{ml} \text {, } \\
\text { on average, in adults within } 24 \text { hours. }\end{array}$ & $\begin{array}{l}\text { Monitor parenteral fluids (control venous infusion); evaluate cutane- } \\
\text { ous turgor and oral mucosa; controlling fluid intake and excreta (water } \\
\text { balance); examining oral mucosae; instruct the patient and family about } \\
\text { proper fluid intake; measure urine output; monitor vital signs; body } \\
\text { weigh daily fasting. }\end{array}$ \\
\hline $\begin{array}{l}\text { Increased heart rate: state in which the heart rate increases. The normal } \\
\text { adult at rest comprises } 60 \text { to } 100 \text { beats per minute. }\end{array}$ & $\begin{array}{l}\text { Control liquids and electrolytes; maintaining a balanced diet; monitor } \\
\text { vital signs; administer prescription drugs; keep the patient calm. }\end{array}$ \\
\hline $\begin{array}{l}\text { Dyspnea: state of discomfort in breathing, caused by the interaction of } \\
\text { various physiological, psychological, social and environmental factors, } \\
\text { which may trigger secondary physiological and behavioral responses. }\end{array}$ & $\begin{array}{l}\text { Monitor oxygen therapy; aspirate tracheostomy cannula; listening for } \\
\text { respiratory sounds through the observation of adventitious sounds; } \\
\text { evaluate peripheral perfusion; elevate bed head; monitor vital signs; } \\
\text { observe respiratory secretions; guide bed rest; aspirate airways through } \\
\text { pulmonary auscultation. }\end{array}$ \\
\hline $\begin{array}{l}\text { Impaired swallowing: A state in which the passage of fluids and foods } \\
\text { decomposed from the mouth to the stomach is difficult to happen. }\end{array}$ & $\begin{array}{l}\text { Investigate the cause of difficulty in swallowing; install nasoenteral cath- } \\
\text { eter in case of intolerance of oral diet. }\end{array}$ \\
\hline $\begin{array}{l}\text { Loneliness: A state in which emotional isolation occurs, feelings of } \\
\text { exclusion, melancholy, low self-esteem and sadness associated with lack } \\
\text { of companionship. }\end{array}$ & $\begin{array}{l}\text { Develop alternative therapies of social interaction and psychological } \\
\text { therapies; motivate the client or people living with AIDS to face the } \\
\text { difficulties; observe client behavior in the inserted environment; provide } \\
\text { psychological support. }\end{array}$ \\
\hline $\begin{array}{l}\text { Fear: A state in which the feeling of threat, anguish or danger occurs, ac- } \\
\text { companied, at times, by an escape response or psychological struggle. }\end{array}$ & $\begin{array}{l}\text { Reassure the client against the present feeling; stimulate coping with } \\
\text { fear; promote individual and group activities of tolerance to fear and } \\
\text { better quality of life. }\end{array}$ \\
\hline $\begin{array}{l}\text { Acceptance of impaired therapeutic regimen: A condition in which } \\
\text { there is no adherence or little adherence to the therapeutic regimen. }\end{array}$ & $\begin{array}{l}\text { Promote educational lectures in group/community about the pathology, } \\
\text { care and complications related to the non-adherence to the treatment; } \\
\text { identify the factors that compromise drug adherence; stimulate the care- } \\
\text { giver/family about the importance of participation in adherence to the } \\
\text { therapeutic regimen of the patient. }\end{array}$ \\
\hline
\end{tabular}




\section{DISCUSSION}

The purpose of systematic practices is to identify the priority needs of nursing care, providing a homogeneous language among the members of the team, thus performing a less intuitive and more scientific kind of care. In this sense, the elaboration and use of care plans implies the representation of guiding instruments for the management of nursing care, as it favors the decision-making process, assisting patients in all their complexity ${ }^{(13)}$.

It is worth mentioning that the results are directed to hospitalized patients and do not apply to patients seen at the outpatient clinic. Among the psychobiological needs, the diagnoses , nursing outcomes: hyperthermia, dehydration, increased heart rate, dyspnea and impaired swallowing were elaborated and validated.

According to ICNP ${ }^{\circledR}$, hyperthermia is defined as a decrease in the ability to regulate the internal thermostat ${ }^{(14)}$. In people living with AIDS, the cause is related to the immune depletion that HIV causes, making them susceptible to infections. Hyperthermia is characterized by the exacerbation of heat caused by the action of toxins that affects the thalamic system, leading to an increase in body temperature. Thus, it can lead to protein denaturation, loss of large amounts of water and, consequently, exacerbate the clinical situation. Therefore, the nurse should guide the patient to recognize the warning signs of hyperthermia; avoid an environment free of air chain and ingestion of ice-cold liquids; reinforce the importance of hydration; in addition to monitoring body temperature, level of consciousness, ingestion and excretion of liquids and signs of electrolyte imbalance ${ }^{(15-16)}$.

In hyperthermia, people living with AIDS lose water and electrolytes, essential in the homeostatic stability and dynamics of the body, developing dehydration, which is considered by $\mathrm{ICNP}^{\circledR}$ as the reduction of the balance of ingestion and elimination of liquids and electrolytes ${ }^{(14)}$.

Dehydration in people living with AIDS does not only arise from hyperthermia, but also from complications related to episodes of vomiting, diarrhea, increased urinary frequency, dysphagia and lesions in the oral and esophageal mucosa, which compromise water intake. With this, the nursing care plan has, as its goal, the volume replacement, being an intervention that tries to attenuate the dehydration and the case of hyperthermia together with antipyretics ${ }^{(16)}$.

It is common to identify, in people living with AIDS, the development of cardiological symptoms, such as increased heart rate due to pathological factors related to heart disease, complications of dehydration and other morbidities, psychological factors such as anxiety and fear, in addition to the relation of the symptomatology as an adverse drug event ${ }^{(17)}$.

Thus, the nursing diagnosis increased heart rate is characterized by any type of organic dysfunction of pathological origin that affects cardiac contractility ${ }^{(14)}$. Factors contributing to rhythm mismatch, known as arrhythmia, are linked to heart disease and drug use, such as antiretroviral drugs of the protein inhibition class $^{(17)}$.

In view of this diagnosis, it is important to carry out the control of liquids and electrolytes; maintain a balanced diet; monitor vital signs; as well as develop strategies to keep the patient calm ${ }^{(18)}$.

The use of the accessory musculature was observed in the majority of patients examined, in the process of inspiration and expiration and respiratory discomfort. The diagnosis of dyspnea, according to ICNP ${ }^{\circledR}$, is conceptualized by respiratory discomforts that present qualitatively different sensations in their intensity. The cause in people living with AIDS may be linked to infections from fungi and bacteria ${ }^{(14)}$.

Thus, among the various nursing interventions, in view of dyspnea, oxygen therapy administration ; aspiration of secretions; pulmonary auscultation; evaluation of peripheral perfusion; bed head elevation; monitoring of vital signs; and orientation in bed rest are recommended actions to be taken ${ }^{(19)}$.

The nursing diagnosis of impaired swallowing is characterized by difficulty in passing fluids and foods from the mouth to the stomach ${ }^{(14)}$. The factors that lead to the appearance of symptoms in people living with AIDS include lack of oral hygiene, candidiasis, herpes simplex, atypical oral ulceration, parotid hypertrophy and lymphadenitis of the head and neck region presenting odynophagia and dysphagia ${ }^{(20)}$.

In view of this diagnosis, it is up to the nurse to investigate the conditions that affect the development of impaired swallowing, as well as to promote assistance strategies to minimize the risk of malnutrition or weight loss, including the implementation of a high protein diet, since AIDS over-catabolizes protein reserves ${ }^{(21)}$.

In the axis of basic human psychosocial needs, the validated nursing diagnoses were acceptance of the therapeutic plan, loneliness and fear. The diagnosis of nursing loneliness is defined as a state of isolation, melancholy and low self-esteem ${ }^{(14)}$. It is linked not only to the health condition, but also to the difficulty of social interaction, psychological trauma caused by the diagnosis of AIDS, stigma and fear of death ${ }^{(2)}$. However, isolation is a strong indication of psychological change and is directly related to depression, indicating the need for emotional therapeutic care ${ }^{(22-23)}$.

In this sense, nursing interventions are focused on the promotion of therapeutic mechanisms that facilitate the process of interlocution between the subjects, that is, people living with AIDS - professionals - society. Therefore, the development of strategies for social reintegration of people living with AIDS are necessary through care behaviors aimed at collective practice and group therapy ${ }^{(22-24)}$.

A study carried out in Portugal clarifies the nursing intervention model that consists of the decision tree, which allows nurses to decide, according to the needs of the patient, the best psychotherapeutic behavior to be adopted. The conducts have two intervention options: based on Psychodynamic Psychotherapy, focused on the unconscious mental processes, and based on Cognitive-Behavioral Therapy, if the problem of the person resides in the emotions, behaviors and dysfunctionalities of the thoughts ${ }^{(24)}$.

The nursing diagnosis fear is characterized by a feeling of anxiety attached to the emotion of a real cause and has the defense function as it generates a reaction in the body to imminent danger ${ }^{(14)}$. However, fear triggers physiological reactions of escape to challenging situations, in this way, the 
presented feeling directly influences the acceptance of the therapeutic regimen, which is impaired, and non-adherence to the drug treatment. Thus, it is important to reassure the patient about the present feeling; stimulate coping with fear; as well as promoting individual and group activities of tolerance to fear and better quality of life ${ }^{(25)}$.

Acceptance of the impaired therapeutic regimen, characterized by poor adherence or non-adherence of pharmacological treatment ${ }^{(14)}$, is associated to adverse effects of drugs, the lack of knowledge about the disease, the factor of having to hide the illness from the family and friends, the use of alcohol and drugs and the forgetfulness of the medication intake ${ }^{(26)}$.

From this perspective, educational actions can be developed to promote the adherence of people living with AIDS to treatment, to identify the factors that compromise drug adherence; to make the caregiver and/or family members aware of the importance of participation in adherence to the patient's therapeutic plan ${ }^{(27)}$. Thus, the nurse is a privileged ally in the support to families with care needs for people living with AIDS and coping with the adversities of the disease ${ }^{(28)}$.

\section{CONCLUSION}

From the data presented, it was possible to elaborate and validate a care plan with the use of $\mathrm{ICNP}^{\circledR}$ version 2015, composed of eight diagnoses, outcomes and 41 nursing interventions. The proposal of a care plan for people living with AIDS opens the design for a scientific nursing practice, optimizing, prioritizing and improving the actions and care interventions to these clients.

The use of Horta's theoretical framework provided the identification of priority needs, so that specific strategies can be articulated and timely outcomes can be quickly obtained, thus reflecting the quality of life of clients. In addition, the use of $\mathrm{ICNP}^{\circledR}$ terminology favored the elaboration of the care plan for people living with AIDS, contributing to the improvement of the nursing practice. The limits of the study were related to the type of non-probabilistic sampling, which does not guarantee the representativeness of the sample.

\section{RESUMO}

Objetivo: Elaborar e validar uma proposta de plano de cuidados de enfermagem para pessoas internadas com Aids, em unidade de infectologia, utilizando a $\mathrm{CIPE}^{\circledR}$ versão 2015. Método: Estudo transversal, seguido de validação de conteúdo, realizado com 20 enfermeiros e 120 pessoas, vivendo com Aids em uma unidade de infectologia de um hospital de doenças infectocontagiosas no Nordeste do Brasil. A trajetória metodológica foi realizada nas seguintes etapas: elaboração dos diagnósticos, resultados de enfermagem; proposta inicial das intervenções de enfermagem; elaboração de um plano de cuidados; e validação do plano por especialistas. Resultados: Foram elaborados 42 diagnósticos; resultados e validados, 33 , os quais apresentaram IVC $\geq 0,80(55,42 \%)$ entre os especialistas. A partir desse quantitativo, elaboraram-se 228 intervenções e 41 obtiveram um IVC $\geq 0,80$ (44,78\%), consideradas validadas. Conclusão: O estudo permitiu identificar e validar diagnósticos, resultados e intervenções de enfermagem para aplicação na prática clínica, com vistas a subsidiar o processo de cuidado às pessoas com Aids.

\section{DESCRITORES}

Síndrome da Imunodeficiência Adquirida; Processos de Enfermagem; Diagnóstico de Enfermagem; Classificação.

\section{RESUMEN}

Objetivo: Elaborar y validar una propuesta de plan de cuidados de enfermería para personas internadas con SIDA en una unidad de infectología, utilizando el CIPE ${ }^{\circledR}$ versión 2015. Método: Estudio transversal con validación de contenido posterior, realizado con 20 enfermeros y 120 personas viviendo con SIDA en una unidad de infectología de un hospital de enfermedades infecto-contagiosas en el nordeste de Brasil. La trayectoria metodológica fue realizada con las siguientes etapas: elaboración de los diagnósticos, resultados de enfermería, propuesta inicial de intervenciones de enfermería y validación de este plan por especialistas. Resultados: fueron elaborados 42 diagnósticos; resultados y validados, 33, los que presentaron IVC $\geq 0,80$ (55,42\%) entre los especialistas. A partir de esta cantidad se elaboraron 229 intervenciones y 41 de ellas obtuvieron un IVC $\geq 0,80$ (44,78\%) siendo consideradas validadas. Conclusión: El estudio permitió identificar y validar diagnósticos, resultados e intervenciones de enfermería para aplicación en la practica clínica, con el fin de mejorar el proceso de cuidado a las personas con SIDA.

\section{DESCRIPTORES}

Sindrome de Inmunodificiencia Adquirida; Procesos de Enfermería; Diagnóstico de Enfermería; Classificación.

\section{REFERÊNCIAS}

1. Oliveira RM, Silva LMS. Dor associada à Aids: perspectiva de enfermeiros e médicos. Rev Bras Enferm. 2014;67(1):54-61 .

2. Sousa CSO, Silva AL. HIV/AIDS care according to the perspective of healthcare providers. Rev Esc Enferm USP [Internet]. 2013 Aug [cited 2015 Mar 02];47(4):907-14. Available from: http://www.scielo.br/pdf/reeusp/v47n4/en_0080-6234-reeusp-47-4-0907.pdf

3. Faria JO, Silva GA. Diagnósticos de enfermagem em pacientes com AIDS: abordagem baseada no modelo conceitual de Horta. Rev RENE. 2013;14(2):290-300.

4. Garcia TR, Nóbrega MML. A terminologia CIPE e a participação do centro CIPE brasileiro em seu desenvolvimento e disseminação. Rev Bras Enferm. 2013;66(n.esp):142-50.

5. Regis LFLV, Porto IS. Basic human needs of nursing professional situations of (dis)satisfaction at work. Rev Esc Enferm USP [Internet]. 2011 [cited 2015 Mar 02];45(2):332-8. Available from: http://www.scielo.br/pdf/reeusp/v45n2/en_v45n2a04.pdf 
6. Souza Neto V L, Andrade LL, Agra G, Costa MML, Silva RAR. Profile of nursing diagnoses of hospitalized patients in an infectious disease unit. Rev Gaúcha Enferm [Internet]. 2015 [cited 2016 June 23];36(3):79-85. Available from: http://www.scielo.br/pdf/rgenf/v36n3/19831447-rgenf-36-03-00079.pdf

7. Siqueira MCF, Bittencourt GKGD, Nóbrega MML, Nogueira JA, Silva AO. Term base for nursing practices with elderly women with HIV/ AIDS. Rev Gaúcha Enferm. [Internet]. 2015 [cited 2016 June 23];36(1):28-34. Available from: http://www.scielo.br/pdf/rgenf/v36n1/19831447-rgenf-36-01-00028.pdf

8. Miot HA. Tamanho da amostra em estudos clínicos e experimentais. J Vasc Bras. 2011;10(4):275-8.

9. Melo DM, Barbosa AJG. O uso do Mini-Exame do Estado Mental em pesquisas com idosos no Brasil: uma revisão sistemática. Ciênc Saúde Coletiva [Internet]. 2015[citado 2015 dez. 20];20(12). Disponível em: http://www.scielo.br/pdf/csc/v20n12/1413-8123-csc-20-12-3865.pdf

10. Fehring RJ. Methods to validate nursing diagnoses. Heart Lung.1987;16(6):625-9.

11. Gordon M, Murphy CP, Candee D, Hiltunen E. Clinical judgment: an integrated model. ANS Adv Nurs Sci.1994;16(4):55-70.

12. Cubas MR, Carvalho CMG, Malucelli A, Denipote AGM. Mapeamento dos termos dos eixos tempo, localização, meio e cliente entre versões da CIPE ${ }^{\circledR}$ e CIPESC ${ }^{\circledR}$. Rev Bras Enferm [Internet]. 2011 [citado 2015 set. 15];64(6):1100-5. Disponível em: http://www.scielo.br/ $\mathrm{pdf} / \mathrm{reben/v64n6/v64n6a17.pdf}$

13. Cavalcante AMRZ, BrunoriEHFR, Lopes CT, Silva ABV, Herdman TH. Nursing diagnoses and interventions for a child after cardiac surgery in an intensive care unit. Rev Bras Enferm. 2015;68(1):155-60.

14. Conselho Internacional de Enfermeiros. Classificação Internacional para a Prática de Enfermagem - CIPE: versão 2.0. São Paulo: Algol; 2011

15. King MA, Clanton TL, Laitano O. Hyperthermia, dehydration, and osmotic stress: unconventional sources of exercise-induced reactive oxygen species. Am J Physiol Regul Integr Comp Physiol. 2015;310(2):R105-14.

16. Mahan LK, Stump S. Krause: alimentos, nutrição e dietoterapia. Rio de Janeiro: Elsevier; 2011.

17. Araújo AA, Nobrega MML, Garcia TR. Nursing diagnoses and interventions for patients with congestive heart failure using the ICNP ${ }^{\circledR}$. Rev Esc Enferm USP [Internet]. 2013 [cited 2015 Oct 07];47(2):380-7. Available from: http://www.scielo.br/pdf/reeusp/v47n2/en_16.pdf

18. Sousa P. Investigação em enfermagem: um percurso ibero-americano. Rev Cuid. 2014;5(1):583-4.

19. Gonçalves A, Nunes L, Sapeta P. Controlo da dispneia: estratégias, farmacológicas e não farmacológicas, para o seu alívio num contexto de cuidados paliativos: revisão sistemática da literatura [Internet]. 2012 [citado 2015 abr 21]. Disponível em: http://hdl.handle. net/10400.11/1475

20. Coccia CB, Palkowski GH, Schweitzer B, Motsohi T, Ntusi NA. Dyspnoea: pathophysiology and a clinical approach. Afr Med. 2016;106(1):32-6.

21. Shevlin M, Murphy S, Murphy J. Adolescent loneliness and psychiatric morbidity in the general population: identifying "at risk" groups using latent class analysis. Nordic J Psychiatry. 2014;68(8):633-9.

22. Brasileiro ME, Cunha LC. Diagnósticos de enfermagem em pessoas acometidas pela síndrome da imunodeficiência adquirida em terapia antirretroviral. Rev Enferm UERJ [Internet]. 2011 [citado 2015 set. 15];19(3):392-6. Disponível em: http://www.facenf.uerj.br/v19n3/ v19n3a09.pdf

23. Ferreira DC, Favoreto CAO. A análise da narrativa dos pacientes com HIV na construção da adesão terapêutica. Physis. 2011;12(3):917-36.

24. Sampaio F, Sequeira C, Canut TL. A intervenção psicoterapêutica em enfermagem de saúde mental: conceitos e desafios. Rev Port Enferm Saúde Ment. 2014;(n.esp.1):103-8.

25. Souza Neto VL, Andrade LL, Agra G, Costa MML, Silva RAR. Perfil diagnóstico de enfermagem de pacientes hospitalizados em unidade de infectologia. Rev Gaúcha Enferm [Internet]. 2015 [citado 2015 set. 14];36(3):79-85. Disponível em: http://www.scielo.br/pdf/rgenf/ v36n3/pt_1983-1447-rgenf-36-03-00079.pdf

26. Rocha GSA, Angelim RCM, Andrade ARL, Aquino JM, Abrão FMS, Costa AM. Cuidados de enfermagem aos indivíduos soropositivos: reflexão à luz da fenomenologia. Rev Min Enferm. 2015;19(2):258-61 .

27. Paschoal EP, Santo CCE, Gomes AMT, Santos Él, Oliveira DC, Pontes APM. Adesão à terapia antirretroviral e suas representações para pessoas vivendo com HIV/AIDS. Rev Esc Anna Nery. 2014;18(1):32-40.

28. Martins MM, Fernandes CS, Gonçalves LHT. A família como foco dos cuidados de enfermagem em meio hospitalar: um programa educativo. Rev Bras Enferm. 2012;65(4):685-90. 